\title{
ANALISIS PERSEDIAAN BERAS PADA TOKO BALI YASA LUWUK BANGGAI
}

\author{
Zulfikar Jaka Putera Djalamang ${ }^{1}$, Nanang Qosim ${ }^{2}$, Hasan $^{3}$ \\ (Dosen Fakultas Ekonomi Universitas Alkhairaat)
}

\begin{abstract}
ABSTRAK
Penelitian ini mengkaji tentang persediaan beras pada Toko Bali Yasa Luwuk Banggai tahun 2020, lebih spesifik terkait dengan pengelolaan persediaan dalam memenuhi kebutuhan yang di inginkan di pasaran. Manajemen persediaan yang efektif seringkali merupakan kunci keberhasilan operasi perusahaan. Manajemen berusaha untuk mempertahankan kualitas dan jenis persediaan yang cukup untuk memenuhi permintaan konsumen, tapi di sisi lain manajemen juga harus menghindarkan biaya penyimpanan persediaan yang terlalu tinggi dan juga tidak terlalu rendah. Persediaan yang terlalu kecil akan menimbulkan kekecewaan konsumen, sebaliknya persediaan yang terlalu tinggi akan menyebabkan biaya penyimpanan dan pemeliharaan persediaan akan melambung. Tujuan penelitian ini di lakukan untuk mengetahui jumlah persediaan beras yang paling optimal pada Toko Bali Yasa Luwuk Banggai dengan menggunakan beberapa metode yaitu Total Inventori Cost (TIC), Economi Order Quantity (EOQ), Safety Stock dan Reorder Point (ROP). Jenis data yang di gunakan adalah jenis data kuantitatif dengan menggunakan sumber data sekunder. Dari hasil penelitian serta pengolahan data yang telah dilakukan, diperoleh bahwa dalam waktu satu tahun Toko Bali Yasa melakukan pemesanan beras sebanyak 60 kali pemesanan dengan jumlah sebanyak 12.000 sak beras dengan total biaya persediaan sebesar Rp. 147.400.000,-. Untuk mengoptimalkan persediaan tersebut menggunakan metode EOQ diperoleh hasil bahwa pemesanan beras yang dilakukan Toko Bali Yasa sebanyak 60 kali pertahun tidak efisien dan tidak efektif atau belum optimal. Dari hasil perhitungan dengan menggunakan metode EOQ diperoleh hasil pemesanan yang optimal yaitu sebanyak 20 kali pesan pertahun dengan jumlah pemesanan sekali pesan 592 sak dengan biaya persediaan sebesar Rp. 81.092.540,-. Penerapan metode ini dapat menghemat pengeluaran biaya Toko Bali Yasa sebesar Rp. 66.307.460,-. Usaha ini dapat menerapkan metode EOQ dengan menggunakan turunan rumus dari Safety Stock, bahwa Toko Bali Yasa harus menyediakan persedian sebanyak 267 sak beras sebelum melakukan pemesanan kembali atau Reorder Point (ROP) pada saat persediaan beras berjumlah 366 sak.
\end{abstract}

Kata Kunci : Persediaan Optimal, TIC, EOQ, ROP, dan Safety Stock.

\section{LATAR BELAKANG}

Kebutuhan hidup yang terpenting bagi manusia setelah udara dan air adalah kebutuhan pangan. Pangan merupakan kebutuhan pokok bagi manusia untuk bertahan hidup. Kebutuhan pangan yang pokok bagi masyarakat Indonesia adalah nasi yang berasal dari beras. Ketersediaan beras erat kaitannya dengan produksi padi para petani. Jika cuaca mendukung, maka produksi padi yang dihasilkan akan baik dan berlimpah. Namun, jika cuaca tidak mendukung, bisa mengakibatkan gagal panen sehingga produksi padi tidak maksimal.

Beras merupakan makanan pokok masyarakat Indonesia sehingga mendorong pemerintah melalui Perum Bulog ikut serta berupaya memenuhi kebutuhan akan beras ini bersama dengan pihak swasta lainnya. Agar tujuan pemenuhan beras dapat dicapai maka diperlukan perencanaan dan manajemen persediaan yang terstruktur dan terorganisasi agar persediaan yang dilakukan dapat memenuhi kebutuhan beras nasional. 
Persediaan merupakan hal terpenting dalam suatu perusahaan. Setiap perusahaan memerlukan adanya suatu persediaan, baik perusahaan dagang, perusahaan jasa maupun perusahaan manufaktur. Persediaan dapat berupa barang mentah, barang dalam proses, atau barang jadi yang menunggu proses penjualan atau pengiriman. Kurangnya persediaan dapat menimbulkan resiko apabila perusahaan tersebut tidak dapat memenuhi permintaan pelanggannya.

Menurut (Sangkota, 2020) Sistem persediaan diartikan sebagai serangkaian kebijakan dari pengendalian yang memonitor tingkat persediaan yang harus dijaga, kapan persediaan harus disediakan dan berapa pesanan yang harus dilakukan. Pemesanan yang dilakukan secara optimal dilihat dari jumlah atau besarnya pesanan yang diadakan hendaknya menghasilkan biaya persediaan yang minimal.

Kasmir, (2010:264) menyatakan bahwa persediaan memiliki peran yang sangat penting dalam perusahaan yang bergerak dibidang produksi, baik persediaan bahan mentah atau bahan setengah jadi. Menurutnya ada tiga alasan tentang pentingnya persediaan bagi perusahaan yaitu "adanya unsur ketidakpastian persediaan, adanya ketidakpastian pasokan, dan adanya unsur ketidakpastian tenggang waktu pesanan".

Penelitian ini dilakukan pada Toko Bali Yasa Luwuk untuk mengkaji pengelolaan persediaannya agar mampu memenuhi kebutuhan yang diinginkan oleh pasar. Namun seringkali dalam praktiknya, ketersediaan persediaan tidak sesuai dengan kebutuhan, pada saat tertentu tidak dapat dipenuhi karena kehabisan stok atau permintaan yang meningkat terus. Kemudian juga seringkali, kualitas persediaan tidak sesuai dengan harapan. Misalnya, terjadi kerusakan terhadap persediaan sehingga pada akhirnya akan merugikan perusahaan itu sendiri.

Berikut adalah tabel persediaan beras pada Toko Bali Yasa Luwuk Banggai pada tahun 2020:
Tabel 1

Data Pemesanan Beras Pada Toko Bali Yasa Luwuk Banggai

\begin{tabular}{|c|l|c|}
\hline No & \multicolumn{1}{|c|}{ Bulan } & Pemesanan (Sak) \\
\hline 1 & Januari & 1.200 \\
\hline 2 & Februari & 1.000 \\
\hline 3 & Maret & 1.400 \\
\hline 4 & April & 800 \\
\hline 5 & Mei & 1.000 \\
\hline 6 & Juni & 800 \\
\hline 7 & Juli & 1.200 \\
\hline 8 & Agustus & 800 \\
\hline 9 & September & 1.000 \\
\hline 10 & Oktober & 1.200 \\
\hline 11 & November & 800 \\
\hline 12 & Desember & 12.000 \\
\hline \multicolumn{2}{|c|}{ Total } & Sumber Data: Toko Bali Yasa \\
\hline
\end{tabular}

Luwuk Banggai, Tahun 2020.

Dari data yang ditampilkan diatas, dapat kita lihat bahwa pemesanan beras setiap bulannya mengalami fluktuasi. Ketidaktetapan pemesanan beras pada setiap bulannya ini disebabkan karena frekuensi pemesanan beras pada setiap bulannya berbeda, hal ini tidak terlepas dari jumlah penjualan kepada konsumen yang setiap bulannya mengalami fluktuasi. Berikut data penjualan beras Toko Bali Yasa :

Tabel 2

Data Penjualan Beras Pada CV. Bali Yasa tahun 2019

\begin{tabular}{|c|l|c|}
\hline No & \multicolumn{1}{|c|}{ Bulan } & Penjualan (Sak) \\
\hline 1 & Januari & 1000 \\
\hline 2 & Februari & 800 \\
\hline 3 & Maret & 1200 \\
\hline 4 & April & 600 \\
\hline 5 & Mei & 750 \\
\hline 6 & Juni & 950 \\
\hline 7 & Juli & 650 \\
\hline 8 & Agustus & 1000 \\
\hline 9 & September & 650 \\
\hline 10 & Oktober & 900 \\
\hline 11 & November & 1050 \\
\hline 12 & Desember & 650 \\
\hline & TOTAL & 10.200 \\
\hline
\end{tabular}

Tahun 2020. 
Pada data penjualan beras dalam tabel diatas, dapat dilihat bahwa penjualan beras sepanjang tahun 2019 juga mengalami fluktuasi atau ketidaktetapan jumlah penjualan pada setiap bulannya, yang dimana penjualan terbanyak terjadi pada bulan Maret yaitu sebanyak 1.200 sak beras, sedangkan penjualan terendah terjadi pada bulan April yaitu sebanyak 600 sak beras, dengan total penjualan sebanyak 10.200 sak pertahun.

\section{Tujuan Penelitian}

Tujuan penelitian ini adalah :

1) Untuk mengetahui jumlah kebutuhan persediaan beras pada Toko Bali Yasa Luwuk Banggai

2) Untuk mengetahui dan menganalisa pengelolaan persediaan beras yang optimal pada Toko Bali Yasa Luwuk Banggai.

\section{TINJAUAN PUSTAKA}

\section{Tinjauan Pustaka}

Pengertian Manajemen

Manajemen adalah ilmu dan seni yang mengatur proses pemanfaatan sumber daya manusia secara efektif, dengan di dukung oleh sumber-sumber lainnya dalam suatu organisasi untuk mencapai tujuan. (Anthoillah, 2010 : 14)

Richard L. (2002:8) Manajemen merupakan pencapaiaan sasaran-sasaran organisasi dengan cara yang efektif dan efesien melalui perencanaan pengorganisasian, kepemimpinan dan pengendalian sumberdaya organisasi.

\section{Pengertian Manajemen Operasional}

Herjanto (2007 : 2), juga berpendapat bahwa manajemen operasional ialah suatu kegiatan yang berhubungan dengan pembuatan sebuah barang, jasa dan kombinasinya, yang melalui proses transformasi dari sumber daya produksi yang menjadi keluaran yang diinginkan.

Stevenson (2009 : 4) menyatakan bahwa manajemen operasional ialah sebuah sistem manajemen atau serangkaian proses dalam suatu pembuatan produk atau penyediaan jasa.

Subagyo (2000 : 1) menyatakan bahwa manajemen operasional adalah penerapan ilmu manajemen untuk mengatur seluruh kegiatan produksi atau operasional agar dapat dilakukan secara efisien.

Heizer dan Rander (2009 : 4) menyatakan bahwa manajemen operasional ialah sebuah serangkaian kegiatan yang menghasilkan sebuah nilai dalam bentuk barang dan jasa dengan mengubah suatu input menjadi output.

\section{Pengertian Persediaan}

Kasmir, (2010 : 264) persediaan adalah sejumlah barang yang harus di sediakan oleh suatu perusahaan pada suatu tempat tertentu, artinya adanya sejumlah barang yang di sediakan perusahaan guna memenuhi kebutuhan produksi atau penjualan barang dagangan. Sedangkan tempat tertentu dapat berupa gudang sendiri atau gudang perusahaan lain atau melalui pesanan yang pada saat di butuhkan dengan harga yang telah di sepakati dapat disediakan.

Assauri, (1978 : 176) persediaan adalah suatu aktiva yang meliputi barang-barang milik perusahaan dengan maksud untuk dijual dalam suatu periode usaha normal atau persediaan barang-barang yang masih dalam pekerjaan proses produksi ataupun persediaan bahan baku yang menunggu penggunaannya dalam suatu proses produksi.

Manullang (2005 : 49) persediaan atau inventory adalah satu elemen utama dari modal kerja yang terus menerus mengalami perubahan, tanpa persediaan perusahaan akan mengalami resiko, yaitu tidak dapat memenuhi keinginan pelanggan atas barang produksi.

Jusup (2005 : 99) persediaan barang dagang adalah elemen yang sangat penting dalam penentuan harga pokok penjualan pada perusahaan dagang eceran, maupun perusahaan dagang parusahaan besar.

\section{Fungsi-Fungsi Persediaan}

Rangkuti, (2007 : 15) menjelaskan beberapa fungsi dari persediaan adalah sebagai berikut :

1) Fungsi decoupling adalah persediaan yang memungkinkan perusahaan dapat memenuhi permintaan pelanggan tanpa tergantung supplier. Persediaan barang jadi di perlukan untuk memenuhi permintaan produk yang tidak pasti dari para konsumen.

2) Fungsi Economic Lot Sizing, fungsi persediaan ini perlu mempertimbangkan penghematan atau potongan pembelian, biaya pengangkutan perunit menjadi lebih murah dan sebagainya. Hal ini di sebabkan karena perusahaan melakukan pembelian dalam kuantitas yang lebih besar di bandingkan dengan biaya-biaya yang timbul karena besarnya persediaan (biaya sewa gedung, investasi, risiko dan sebagainya). 
3) Fungsi antisipasi adalah apabila perusahaan menghadapi fluktuasi permintaan yang dapat di perkirakan dan di ramalkan berdsarkan pengalaman atau data-data masa lalu, yaitu permintaan musiman. Dalam hal ini perusahaan dapat mengadakan persediaan musiman (seasional inventories).

Dilihat dari fungsinya, menurut Eddy Herjanto, fungsi-fungsi persediaan dapat dikelompokkan kedalam empat jenis, yaitu:

1) Fluctuation Stock, merupakan persediaan yang dimaksudkan untuk menjaga terjadi fluktuasi permintaan yang tidak diperkirakan sebelumnya, dan untuk mengatasi bila terjadi kesalahan/ penyimpangan dalam perkiraan penjualan waktu produksi, atau pengiriman barang.

2) Anticipation Stock, merupakan persediaan untuk menghadapi permintaan yang dapat diramalkan, misalnya pada musim permintaan tinggi, tetapi kapasitas produksi pada saat itu tidak mampu memenuhi permintaan. Persediaan ini juga dimaksudkan untuk menjaga kemungkinan sukarnya diperoleh bahan baku sehingga tidak mengakibatkan terhentinya produksi.

3) Lot-size Inventory, merupakan persediaan yang diadakan dalam jumlah yang lebih besar daripada kebutuhan pada saat itu. Persediaan dilakukan untuk mendapatkan keuntungan dari harga barang (berupa diskon) karena membeli dalam jumlah yang besar, atau untuk mendapatkan penghematan dari biaya pengangkutan per unit yang lebih rendah.

4) Pipeline Inventory, merupakan persediaan yang dalam proses pengiriman dari tempat asal ke tempat dimana barang itu akan digunakan. Misalnya barang yang dikirim dari pabrik menuju tempat penjualan, yang dapat memakan waktu beberapa hari atau minggu.

\section{Jenis dan Bentuk Persediaan}

Rangkuti, (2007 : 14) mengemukakan beberapa jenis persediaan dengan karakteristik sendiri dan cara pengelolaannya yaitu :

1) Pesediaan bahan mentah (raw material) yaitu persediaan barang-barang berwujud seperti besi, baja, kayu dan komponen-komponen lainnya yang di gunakan dalam proses produksi.

2) Perseiaan komponen-komponen rakitan (purchase parts/component) yaitu persediaan barang-barang yang terdiri dari komponenkomponen yang di peroleh dari perusahaan lain yang secara langsung dapat di rakit menjadi suatu produk.

3) Persediaan bahan pembantu dan bahan penolong (supplies) yaitu persediaan barangbarang yang di perlukan dalam proses produsi, tetapi bukan merupakan bagian atau komponen barang jadi.

4) Persediaan batrang dalam proses (work in process) yaitu persdiaan barang - barang yang merupakan keluaran dari tiap - tiap bagian dalam proses produksi, atau yang telah di olah menjadi suatu bentuk, tetapi masih harus di proses lebih lanjut menjadi barang jadi.

5) Persediaan barang jadi (finished goods) yaitu persediaan barang - barang yang telah selesai di proses atau di olah dalam pabrik dan siap untuk di jual atau di kirim kepada pelanggan.

\section{Pengendalian Persediaan}

Pengendalian persediaan merupakan tindakan yang sangat penting dalam menghitung berapa jumlah optimal tingkat persediaan yang diharuskan, serta kapan saatnya mengadakan pemesanan kembali. (Rangkuti, 2007)

Menurut (Gulom, 2019) Berkaitan dengan pengendalian persediaan, agar jangan sampai terjadi kekurangan atau kelebihan, maka perlu di lakukan perencanaan scara matang untuk persediaan yang akan datang yang berkaitan erat dengan produksi, harga dan prediksi penjualan. Yang selanjutnya di lakukan pengelolaan serta mengawasi keluar masuknya persediaan, mana yang keluar duluan dan mana yang perlu di masukkan agar tidak terjadi keterlambatan ataupun kerusakan. Pengendalian persediaan di harapkan dapat mengantisipasi secara cepat untuk memenuhi kebutuhan yang mendadak, akibat lonjakan permintaan atau sebaliknya terjadi penurunan penjualan atau produksi dengan berbagai sebab (Kasmir, 2010 : 270).

Pada dasarnya pengendalian persediaan ini di lakukan agar dapat menentukan jumlah persediaan yang optimal dengan menggunakan metode :

1) Total inventory cost (TIC) 
2) Jumlah pesanan optimal (EOQ)

3) Titik pemesanan kembali (ROP)

4) Jumlah cadangan pengaman (Safety Stock)

\section{Biaya-Biaya Persediaan}

Eddy Herjanto (2010 : 242), unsur-unsur biaya yang terdapat dalam persediaan dapat digolongkan menjadi tiga, yaitu :

1) Biaya pemesanan (ordering costs, procurement costs) adalah biaya yang dikeluarkan sehubungan dengan kegiatan pemesanan bahan/ barang, sejak dari penempatan pemesanan sampai tersedianya barang digudang. Biaya pemesanan ini meliputi semua biaya yang dikeluarkan dalam rangka mengadakan pemesanan barang, yang dapat mencakup biaya administrasi dan penempatan order, biaya pemilihan pemasok, biaya pengangkutan dan bongkar muat, biaya penerimaan dan pemeriksaan barang. Biaya pemesanan dinyatakan dalam rupiah (satuan mata uang) per pesanan, tetapi tergantung dari berapa kali pesanan dilakukan. Apabila perusahaan memproduksi persediaan sendiri, tidak membeli dari pemasok, biaya ini disebut sebagai set-up costs, yaitu biaya yang diperlukan untuk menyiapkan peralatan, mesin atau proses manufaktur lain dari suatu rencana produksi. Analog biaya dengan biaya pemesanan, biaya set-up dinyatakan dalam rupiah per run, tidak tergantung dari jumlah yang diproduksi.

2) Biaya penyimpanan (carrying costs, holding costs) adalah biaya yang dikeluarkan berkenaan dengan diadakannya persediaan barang. Yang termasuk biaya ini, antara lain biaya sewa gudang, biaya administrasi pergudangan, gaji pelaksana pergudangan, biaya listrik, biaya modal yang tertanam dalam persediaan, biaya asuransi ataupun biaya kerusakan, kehilangan atau penyusutan barang selama dalam penyimpanan. Biaya modal biasanya merupakan komponen biaya penyimpanan yang terbesar, baik itu berupa biaya bunga kalau modalnya berasal dari pinjaman maupun biaya oportunitas apabila modalnya milik sendiri.

3) Biaya kekurangan persediaan (shortage costs, stockout costs) adalah biaya yang timbul sebagai akibat tidak tersedianya barang pada waktu diperlukan. Biaya kekurangan persediaan ini pada dasarnya bukan biaya nyata (rill), melainkan berupa biaya kehilangan kesempatan. Menurut (Salim, 2020) Dalam perusahaan manufaktur, biaya ini merupakan biaya kesempatan yang timbul misalnya karena terhentinya proses produksi sebagai akibat tidak adanya bahan yang diproses, yang antara lain meliputi biaya kehilangan waktu produksi bagi mesin dan karyawan.

\section{Metode Economic Order Quantity (EOQ)}

Menurut Gitosudarmo (2002:245), Economic Order Quantity (EOQ) merupakan jumlah pembelian yang paling ekonomis yaitu dengan melakukan pembelian secara teratur sebesar EOQ itu maka perusahaan akan menanggung biayabiaya pengadaan bahan yang minimal.

Prawirosentono (2005:93) EOQ adalah jumlah persediaan tidak dalam jumlah terlalu banyak dan terlalu sedikit karena keduanya mengandung resiko.Mengingat jumlah persediaan dipengaruhi jumlah pesanan, berarti persediaan yang optimal terjadi jika jumlah pesanan yang dilakukan secara ekonomis.

Economic Order Quantity (EOQ) adalah jumlah kuantitas barang yang dapat diproleh dengan biaya yang minimal atau sering dikatakan sebagai jumlah pembelian yang optimal (Riyanto, 2001 : 78)

Untuk menghitungkan kuantitas pesanan ekonomis dapat dirumuskan menurut Agustinus (2015 : 69) sebagai berikut :

$$
\begin{aligned}
& \text { EOQ }=\text { Kuantitas pembelian optimal } \\
& \mathrm{S} \text { = Biaya pemesanan setiap kali pesan } \\
& \mathrm{D}=\text { Penggunaan bahan per tahun } \\
& \mathrm{H}
\end{aligned}
$$$$
\text { Keterangan : }
$$$$
\mathrm{EOQ}=\frac{\sqrt{2 S D}}{H}
$$

Metode EOQ adalah metode yang digunakan untuk mencari titik keseimbangan antara biaya pemesanan dengan biaya penyimpanan agar di peroleh suatu biaya minimum.

\section{Total Biaya Persediaan (Total Inventory Cost)}

Biaya-biaya dalam persediaan yang wajib disediakan oleh pabrik atau perusahaan, Martono (2015 : 232-233) dalam pembuatan keputusan yang akan mempengaruhi besarnya jumlah persediaan, biaya-biaya variabel berikut : 
1) Biaya Penyimpanan $(\mathrm{H})$ adalah biaya persediaan terdiri atas biaya-biaya yang bervariasi secara langsung dengan kuantitas persediaan. yang termasuk biaya penyimpanan :

a. Biaya listrik

b. Biaya buruh gudang

c. Biaya asuransi persediaan dan,

d. Biaya kerusakan persediaan yang ditanggung perusahaan

2) Biaya pemesanan atau pembelian (S) adalah biaya-biaya termasuk didalamnya yang dapat dijelaskan :

a. Biaya telepon

b. Biaya pengeluaran surat menyurat

c. Biaya pengiriman ke gudang

d. Biaya administrasi dan umum

e. Biaya pembongkaran barang

3) Biaya kehabisan atau kekurangan bahan (shortage cost) adalah biaya yang timbul apabila persediaan tidak mencukupi adanya permintaan bahan. Biaya yang termasuk biaya kekurangan bahan adalah sbb :
a. Kehilangan penjualan
b. Kehilangan pelanggan
c. Terganggunya operasi

\section{Persediaan Pengamanan (Safety Stock)}

Menurut Widodo (2001:346) persediaan pengaman adalah persediaan minimal yang harus ada atau harus dipertahankan dalam perusahaan.

Persediaan pengamanan merupakan persediaan yang digunakan untuk mencegah kondisi stock out (kehabisan persediaan) untuk menjamin proses terus berjalan (Martono, 2015 : 261).

Adapun faktor-faktor yang menentukan besarnya persediaan pengaman menurut Sofyan Assauri (2004 : 186) adalah :

a. Penggunaan bahan baku rata-rata

b. Faktor waktu atau lead time

c. Penentuan besarnya penyediaan penyelamat

Menurut Riyanto (2001 : 74) adapun faktor-faktor yang mempengaruhi besar kecilnya safety stock suatu perusahaan adalah sebagai berikut :

a. Resiko kehabisan persediaan

b. Hubungan antara biaya penyimpanan digudang disatu pihak dengan biaya-biaya ekstra yang harus dikeluarkan sebagai akibat dari kehabisan persediaan dilain pihak.

\section{Titik Pemesanan Kembali (Reorder Point)}

ROP adalah titik dimana harus diadakan pesanan lagi sedemikian rupa sehingga kedatangan atau penerimaan material yang dipesan datang tepat waktu dimana persediaan safety stock sama dengan nol (Bambang Riyanto, 2001 : 83).

Menurut Herlina (2007) menyatakan bahwa reorder point merupakan titik waktu dimana pemesanan kembali harus dilakukan.

Ada beberapa faktor untuk menentukan Reorder point (ROP) diantaranya :

1) Pengadaan atau stock selama masa pengiriman

2) Tingkat pengamanan yang diinginkan

Riyanto (2001 : 83) juga mengemukakan ada dua faktor yang menentukan titik pemesanan kembali sebagai berikut :

1) Penggunaan material selama tenggang waktu mendapatkan barang

2) Besarnya Safety Stock

Sudana (2011 : 227-228) pada tingkat persediaan beberapa pemesanan harus di lakukan agar barang datang tepat pada waktunya. Reorder point dapat di tentukan dengan cara sebagai berikut :

Keterangan :

$$
\mathrm{ROP}=\text { Lt } \times \mathrm{Q}
$$

ROP $=$ Reorder Point

Lt = Lead time (hari, minggu atau bulan)

$\mathrm{Q}=$ Pemakaian rata-rata (perhari, perminggu, atau perbulan)

EOQ menjawab pertanyaan kapan seharusnya pemesanan dilakukan.Reorder point atau titik waktu pemesanan merupakan fungsi EOQ, waktu tunggu dan tingkat dimana persediaan sudah habis. Waktu tunggu (Lead time) merupakan waktu yang diperlukan untuk menerima kuantitas pesanan ekonomis ketika suatu pesanan dilakukan.

\section{METODE PENELITIAN}

\section{Lokasi Penelitian}

Lokasi penelitian ini dilakukan pada Toko Bali Yasa Luwuk, yang berlokasi di Jl. Jendral Sudirman No. 45 Kel, Simpong Luwuk Banggai Sulawesi Tengah, dengan pertimbangan bahwa usaha ini memiliki perkembangan yang baik dan belum pernah dilakukan penelitian yang berkaitan dengan persediaan beras pada toko ini. Penelitian ini direncanakan akan dilaksanakan mulai bulan Oktober 2020 sampai dengan bulan Desember 2020. 


\section{Jenis dan Sumber Data}

\section{Jenis Data}

Jenis data yang digunakan dalam penelitian ini adalah jenis data kuantitatif. Data kuantitatif adalah jenis data yang dapat diukur atau dihitung secara langsung, yang berupa informasi atau penjelasan yang dinyatakan dengan bilangan atau berbentuk angka (Sugiyono, $2010: 15$ ).

\section{Sumber Data}

Penelitian ini menggunakan Sumber data sekunder. Menurut Sugiyono (2005 : 62) data sekunder yaitu penelitian yang telah diperoleh melalui media perantara atau secara tidak langsung memberikan data kepada peneliti, berupa catatan-catatan dan dokumen-dokumen yang memberikan informsi berkaitan dengan persediaan barang dagangan.

\section{Teknik Pengumpulan Data}

Metode pengumpulan data dalam penelitian ini berupa :

1) Metode dokumentasi yaitu pengumpulan data atau bukti tertulis yang diperoleh dari bagianbagian yang terkait dalam penelitian.

2) Studi Pusaka yaitu dengan mengumpulkan dan mengkaji beberapa literatur pustaka seperti jurnal dan sumber-sumber lainya yang berhubungan dengan penelitian.

3) Teknik wawancara yaitu pengambilan data langsung dengan pemilik perusahaan untuk memberikan informasi yang berkaitan dengan data-data yang diperlukan dalam penelitian ini.

\section{Definisi Operasional Variabel}

1) Persediaan adalah sejumlah barang yang harus disediakan oleh perusahaan pada suatu tempat tertentu. Artinya adanya sejumlah barang yang disediakan perusahaan guna memenuhi kebutuhan produksi atau penjualan barang dagangan. (Kasmir $2005: 50$ )

2) Economic order quantity adalah jumlah kuantitas barang yang dapat diproleh dengan biaya yang minimal atau sering dikatakan sebagai jumlah pembelian yang optimal (Riyanto, $2001: 78$ )

3) Total inventory cost adalah seluruh biayabiaya dalam persediaan yang wajib disediakan oleh pabrik atau perusahaan.
4) Safety Stock adalah persediaan yang digunakan untuk mencegah kondisi stock out (kehabisan persediaan) untuk menjamin proses terus berjalan (Martono, 2015 : 261).

5) Reorder Point adalah titik dimana harus diadakan pesanan lagi sedemikian rupa sehingga kedatangan atau penerimaan material yang dipesan datang tepat waktu dimana persediaan safety stock sama dengan nol (Bambang Riyanto, 2001 : 83).

6) Lead Time adalah jangka waktu antara pemesanan pelanggan dan pengiriman produk akhir.

7) Biaya penyimpanan adalah biaya yang timbul akibat disimpannya suatu barang.

8) Biaya pemesanan adalah biaya yang dikeluarkan dalam rangka mengadakan pemesanan barang, sejak pemesanan dilakukan hingga barang tersebut dikirim.

\section{Teknik Pengukuran Variabel}

Kriteria pengukuran jumlah pesanan yang ekonomis atau EOQ dapat dilakukan dengan dua cara menurut Assauri (2004 : 182) yaitu sebagai berikut :

1) Pendekatan tabel (Tabular Approach) Penentuan jumlah pesanan yang ekonomis dengan tabular approach dilakukan dengan cara menyusun suatu daftar atau tabel jumlah pesanan dan jumlah biaya pertahun.

2) Pendekatan rumus (Formula Approach) Cara penentuan jumlah pesanan ekonomis dengan menurunkan didalam rumus-rumus matematika dapat dilakukan dengan memakai simbol atau notasi.

\section{Teknis Analisis Data}

Analisis data adalah cara mengolah data yang terkumpul kemudian dapat memberikan interprestasi. Alat analisis yang digunakan dalam penelitian ini yaitu Total inventory cost (TIC), Economic order quantity (EOQ) dan Reorder point (ROP).

\section{1) Total Inventory Cost (TIC)}

Menurut Agustinus, (2016:69) Asumsi dasar untuk menggunakan metode EOQ adalah :

$\begin{array}{ll}\text { Biaya pemesanan } \quad= & \text { Frekuensi } \\ \text { pemesanan } \mathrm{x} \text { Biaya pemesanan } & \end{array}$

$$
=\frac{D}{Q} \times S
$$


Biaya penyimpanan $\quad=$ Persediaan rata-rata $\mathrm{x}$ Biaya penyimpanan

$$
=\frac{Q}{2} \times H
$$

Biaya Total

penyimpanan

$$
=\text { Biaya pemesanan }+ \text { Biaya }
$$

$$
=\frac{D}{Q} \times S+\frac{Q}{2} \times H
$$

Keterangan :

TIC = Total inventory cost atau biaya total persediaan

$\mathrm{D} \quad=$ Jumlah kebutuhan dalam setahun

$\mathrm{Q} \quad=$ Jumlah pembeliaan barang rata-rata setahun

$\mathrm{S} \quad=$ Biaya pemesanan setiap kali pesan

$\mathrm{H} \quad=$ Biaya penyimpanan per unit barang

\section{2) Economic Order Quantity (EOQ)}

EOQ adalah jumlah setiap kali pembelian bahan yang disertai biaya minimal sama dengan jumlah pembelian bahan yang paling ekonomis.

Menurut Agustinus, (2016 : 69) Rumus dasar untuk menggunakan metode EOQ :

EOQ terjadi jika biaya Pemesanan = Biaya Penyimpanan $\frac{D}{Q} \times S=\frac{Q}{2} \times H$

$\frac{D x S}{Q}=\frac{Q}{2} \times H$

$\mathrm{Q}^{2} \times \mathrm{H}=2 \times \mathrm{D} \times \mathrm{S}$

$\mathrm{Q}^{2}=\frac{2 X D X S}{H}$

$\mathrm{Q}=\frac{\sqrt{2 x D \times S}}{H}$

Keterangan :

$\mathrm{D} \quad=$ Jumlah kebutuhan dalam 1 tahun

$\mathrm{S}=$ Biaya pemesanan setiap kali melakukan pembeliaan

$\mathrm{H} \quad=$ Biaya penyimpanan per unit selama satu tahunp

\section{3) Pengamanan Persediaan (Safety Stock)}

Pengertian persediaan pengaman (Safety Stock) menurut Freddy Rangkuty (2004) adalah persediaan tambahan yang diadakan untuk melindungi atau menjaga kemungkinan terjadinya kekurangan bahan (Stock Out).

Menurut Haizer dan Render (2011 : 322) menyatakan bahwa konsep persediaan pengamanan adalah suatu persediaan tambahan yang memungkinkan permintaan yang tidak seragam dan menjadi sebuah cadangan.

Perhitungan persediaan pengaman dapat digunakan dengan metode statistik yang membandingkan kebutuhan rata-rata barang dan pemakaian barang yang sesungguhnya, yakni perhitungan Standar Deviation (Ricky Martono, $2015: 241)$

Untuk mengetahui jumlah persediaan pengamanan yang optimal agar tidak terjadi kelebihan ataupun kekurangan persediaan dapat menggunakan rumus sebagai berikut :

Rumus :

SafetyStock=pemakaian maksimum x Lead time

Standar Deviation $=\frac{\sqrt{\sum(x-x)^{2}}}{n}$

Dimana :

$\mathrm{SD}=$ Standar Devisiasi

$\mathrm{x} \quad=$ Kebutuhan barang dalam setahun

$\boldsymbol{x} \quad=$ Pembelian dalam sekali pesan

$\mathrm{n} \quad=$ Jumlah pemesanan dalam setahun

\section{4) Titik Pemesanan Kembali atau Reorder Point (ROP)}

Untuk mengetahui seberapa besar penggunaan barang dalam perhari yaitu dengan menghitung total kebutuhan dan rata-rata jumlah tenaga kerja atau karyawan selama setahun dalam perusahaan. Rumus :

$$
\mathrm{u}=\frac{Q}{t}
$$

Keterangan :

$\mathrm{Q} \quad=$ Jumlah kebutuhan barang setahun

$\mathrm{t} \quad=$ Rata-rata jumlah kerja karyawan

Menurut Ricky Martono (2015 : 239) cara untuk menetapkan ROP yaitu dengan rumusnya :

$$
R O P=(u \times L)+S S
$$

Keterangan :

$\mathrm{ROP}=$ Reorder Point atau waktu pemesan ulang

$\mathrm{U} \quad=$ Tingkat kebutuhan perunit waktu

$\mathrm{L} \quad=$ Lead time atau waktu tenggang

SS $=$ Safety Stock atau persediaan pengaman

HASIL PENELITIAN DAN PEMBAHASAN

Hasil Penelitian

A. Perhitungan Total Inventory Cost (TIC) 
Tabel 3

Data Persediaan Beras Pada Toko Bali Yasa Luwuk Banggai tahun 2020

\begin{tabular}{|l|r|l|l|}
\hline \multicolumn{1}{|c|}{ Bulan } & $\begin{array}{c}\text { Pemesanan } \\
\text { (Sak) }\end{array}$ & $\begin{array}{c}\text { Harga } \\
\text { Satuan/Sak }\end{array}$ & $\begin{array}{c}\text { Jumlah } \\
\text { Penjualan/Bulan }\end{array}$ \\
\hline Januari & 1.200 & Rp. 400.000,- & Rp.480.000.000,- \\
\hline Februari & 1.000 & Rp. 400.000,- & Rp.400.000.000,- \\
\hline Maret & 1.400 & Rp. 400.000,- & Rp.560.000.000,- \\
\hline April & 800 & Rp. 400.000,- & Rp.320.000.000,- \\
\hline Mei & 800 & Rp. 400.000,- & Rp.320.000.000,- \\
\hline Juni & 1.000 & Rp. 400.000,- & Rp.400.000.000,- \\
\hline Juli & 800 & Rp. 400.000,- & Rp.340.000.000,- \\
\hline Agustus & 1.200 & Rp. 400.000,- & Rp.480.000.000,- \\
\hline September & 800 & Rp. 400.000,- & Rp.320.000.000,- \\
\hline Oktober & 1.000 & Rp. 400.000,- & Rp.400.000.000,- \\
\hline November & 1.200 & Rp. 400.000,- & Rp.480.000.000,- \\
\hline Desember & 800 & Rp. 400.000,- & Rp.320.000.000,- \\
\hline TOTAL & & 12.000 & Rp4.800.000.000 \\
\hline
\end{tabular}

Sumber : Toko Bali Yasa dan diolah, 2020

\section{1) Pembelian Rata-Rata Persediaan Beras}

Dalam menentukan jumlah pembelian rata-rata beras pada Toko Bali Yasa Luwuk Banggai dapat dihitung dengan cara sebagai berikut :

Pembelian Rata-rata $=$ Total Jumlah Pemesanan

Frekuensi Pemesanan Dalam 1 tahun

$=\underline{12.000}$

60 kali

$=200 \mathrm{Sak}$

Jadi, rata-rata pembelian beras yang harus dilakukan adalah sebanyak 200 sak setiap kali pemesanan.

\section{2) Biaya Pemesanan}

Biaya Pemesanan yaitu biaya yang dikeluarkan setiap proses pemesanan beras. Biaya pemesanan setiap kali dilakukan pemesanan terdiri dari biaya telpon, biaya pengiriman barang, serta biaya bongkar muat barang. Untuk jenis biaya dan jumlah biaya yang di keluarkan dalam setiap kali pemesanan akan di lampirkan dalam tabel sebagai berikut :
Tabel 4

Biaya Pemesanan Beras di Bali Yasa Luwuk Banggai

\begin{tabular}{|c|l|c|}
\hline No & $\begin{array}{l}\text { Jenis-Jenis Biaya } \\
\text { Pemesanan }\end{array}$ & Jumlah \\
\hline 1 & Biaya telepon & Rp. 1.500.000,- \\
\hline 2 & $\begin{array}{l}\text { Biaya pengiriman } \\
\text { barang }\end{array}$ & Rp. 70.000.000,- \\
\hline 3 & $\begin{array}{l}\text { Biaya bongkar } \\
\text { muat barang }\end{array}$ & Rp. 48.500.000,- \\
\hline & \multicolumn{1}{|c|}{ Total } & Rp. 120.000.000,- \\
\hline
\end{tabular}

Sumber : Toko Bali Yasa dan diolah, 2020.

Perhitungan biaya pemesanan dapat di lakukan dengan rumus berikut :

Biaya Pemesanan $=$ Total Biaya Pemesanan

Frekuensi Pemesanan dalam 1 Tahun

$$
\begin{aligned}
& =\frac{\text { Rp. } 120.000 .000}{60 \mathrm{Kali}} \\
& =\text { Rp. } 2.000 .000,-
\end{aligned}
$$

3) Biaya Penyimpanan

Biaya penyimpanan adalah biaya-biaya yang dikeluarkan karena perusahaan melakukan penyimpanan persediaan beras dalam jangka waktu tertentu. Biaya penyimpanan yang dikeluarkan oleh Gudang Bali Yasa dimuat dalam rincian sebagai berikut :

Table 4.3

Biaya Penyimpanan Beras

Pada Gudang Bali Yasa Luwuk Banggai

\begin{tabular}{|c|l|l|}
\hline No & \multicolumn{1}{|c|}{$\begin{array}{c}\text { Jenis- Jenis Biaya } \\
\text { Penyimpanan }\end{array}$} & \multicolumn{1}{|c|}{ Jumlah } \\
\hline 1 & Biaya Listrik & Rp. 2.000.000,-- \\
\hline 2 & Biaya buruh Gudang & Rp.20.400.000,- \\
\hline 3 & $\begin{array}{l}\text { Biaya kerusakan } \\
\text { persediaan }\end{array}$ & Rp. 5.000.000,- \\
\hline & Total & Rp.27.400.000,- \\
\hline
\end{tabular}

Sumber : Toko Bali Yasa dan diolah, 2020

Biaya penyimpanan per sak beras dapat dihitung dengan menggunakan rumus :

Biaya Penyimpanan $=$ Total Biaya Penyimpanan Rata-rata Pembelian Beras $=\underline{\text { Rp. } 27,400.000}$

$=$ Rp. 137.000,$200 \mathrm{Sak}$

4) Perhitungan Total Biaya Persediaan (TIC) Jumlah barang yang dibeli $(\mathrm{D})=12.000 \mathrm{Sak}$ Biaya penyimpanan $(\mathrm{H})=137.000$ 
Biaya pemesanan $(\mathrm{S})=2.000 .000$

Biaya pembelian rata-rata $(\mathrm{Q})=200 \mathrm{Sak}$

$\mathrm{TIC}=\underline{\mathrm{D}} \times \mathrm{S}+\underline{\mathrm{Q}} \times \mathrm{H}$

$$
\mathrm{Q} \quad 2
$$

TIC $=\frac{12.000}{200} \times 2.000 .000+\frac{200}{2} \times 137.000$

$\mathrm{TIC}=(60 \times$ Rp. 2.000 .000$)+(100 \times$ Rp. 137.000 $)$

TIC = Rp. 120.000.000,- + Rp. 13.700.000,-

TIC = Rp. 133.700.000,-

Jadi, jumlah biaya total persediaan (TIC) yang harus ditanggung oleh Toko Bali Yasa yaitu sebesar Rp. 133.700.000,-

\section{Perhitungan metode Economic Order Quantity (EOQ)}

Menentukan berapa jumlah kuantitas pembelian optimal dengan menggunakan metode EOQ, adapun perhitungan kuantitas pembelian optimal yaitu sebagai berikut :

$$
\begin{aligned}
& \text { EOQ }=\frac{\sqrt{2 . S . D}}{H} \\
& \text { EOQ }=\frac{\sqrt{2(2.000 .000 \times 12.000)}}{137.000} \\
& \text { EOQ }=\frac{\sqrt{2(24.000 .000 .000)}}{137.000} \\
& \text { EOQ }=\frac{\sqrt{48.000 .000 .000}}{137.000} \\
& \text { EOQ }=\sqrt{350.364} \\
& \text { EOQ }=592 \text { Sak. }
\end{aligned}
$$

Jadi, jumlah pemesanan yang optimal yaitu dengan menggunakan metode EOQ sebesar 592 sak beras.

Setelah pemesanan optimal diketahui dengan menggunakan metode EOQ maka, frekuensi pemesanan $(\mathrm{F})$ dengan metode ini dapat dihitung dengan menggunakan rumus sebagai berikut:

$$
\begin{aligned}
\mathrm{F} & =\frac{\mathrm{D}}{\mathrm{EOQ}} \\
& =\frac{12.000}{592} \\
& =20,27=20
\end{aligned}
$$

Jadi, Frekuensi pemesanan beras dilakukan Toko Bali Yasa sebanyak 20 kali selama satu tahun. Dengan hasil perolehan dari EOQ di atas, maka dapat dicari total biaya persediaan yang optimal yaitu dengan menggunakan rumus sebagai berikut:

$$
\begin{aligned}
& \text { TIC }=\frac{\mathrm{D}}{\mathrm{Q}} \times \mathrm{S}+\frac{\mathrm{Q} \times \mathrm{H}}{2} \\
& \text { TIC }=\frac{12.000 \times 2.000 .000+\frac{592}{592} \times 137.000}{2} \\
& \text { TIC }=(20,27 \times 2.000 .000)+(296 \times 137.000) \\
& \text { TIC }=\text { Rp. } 40.540 .540+40.552 .000
\end{aligned}
$$

TIC = Rp. 81.092.540,-

Jadi, total biaya persediaan (TIC) yang optimal yaitu dengan menggunakan metode EOQ sebesar Rp. 81.092.540,-

Penentuan Persediaan Pengaman (Safety Stock) Untuk mengatasi keadaan yang tidak diinginkan atau kehabisan persediaan yang diakibatkan oleh keterlambatan kedatangan pengirim barang diperlukan sejumlah persediaan tambahan, dengan adanya persediaan pengaman diharapkan perusahaan tidak akan terjadi lagi kehabisan persediaan yang tidak diharapkan maka digunakan metode statistik yang membandingkan rata-rata beras dan pemakaian beras yang sesungguhnya. Perhitungannya dapat dilihat pada tabel dibawah :

Tabel 5

Perhitungan Standar Deviasi

\begin{tabular}{|l|c|c|c|c|}
\hline \multicolumn{1}{|c|}{ Bulan } & $\begin{array}{c}\text { Kebutuhan } \\
\text { Beras }\end{array}$ & $\mathbf{x}^{\mathbf{6}}$ & $\begin{array}{c}(\mathbf{x}- \\
\left.\mathbf{x}^{6}\right)\end{array}$ & $\left(\mathbf{x}-\mathbf{x}^{\mathbf{6}}\right)^{\mathbf{2}}$ \\
\hline Januari & 1.200 & 1000 & 200 & 40.000 \\
\hline Februari & 1.000 & 1000 & 0 & 0 \\
\hline Maret & 1.400 & 1000 & 400 & 160.000 \\
\hline April & 800 & 1000 & -200 & 40.000 \\
\hline Mei & 800 & 1000 & -200 & 40.000 \\
\hline Juni & 1.000 & 1000 & 0 & 0 \\
\hline Juli & 800 & 1000 & -200 & 40.000 \\
\hline Agustus & 1.200 & 1000 & 200 & 40.000 \\
\hline September & 800 & 1000 & -200 & 40.000 \\
\hline Oktober & 1.000 & 1000 & 0 & 0 \\
\hline November & 1.200 & 1000 & 200 & 40.000 \\
\hline Desember & 800 & 1000 & -200 & 40.000 \\
\hline $\begin{array}{l}\text { Jumlah } \\
\text { Total }\end{array}$ & 12.000 & 12.000 & 0 & 480.000 \\
\hline
\end{tabular}

Sumber : Data Olahan, 2020

Jadi, untuk mengetahui jumlah rata-rata beras maka menggunakan rumus sebagai berikut :

$$
\begin{array}{ll}
\mathrm{SD} & =\frac{\sqrt{\sum(x-x)^{2}}}{n} \\
\mathrm{SD} & =\frac{\sqrt{480.000}}{60} \\
\mathrm{SD} & =\sqrt{8.000} \\
\mathrm{SD} & =89
\end{array}
$$

Jadi, diketahui pemakaian maksimum atau jumlah rata-rata beras sebesar 89 sak dengan waktu tunggu (lead time) selama 3 hari, jika dimasukan dalam rumus safety stock sebagai berikut:

Safety Stock = (Pemakaian maksimum/pemakaian rata-rata) x Lead time $=89 \times 3$ (Lead time) 


$$
=267 \mathrm{Sak}
$$

\section{Perhitungan Titik Pemesanan Kembali (Reorder Point)}

Toko Bali Yasa Luwuk Banggai memiliki waktu tunggu produk beras adalah selama 3 hari atau biasa disebut Lead time.Dengan rata-rata waktu kerja karyawan 360 hari dalam setahun. Sebelum menghitung Reorder point maka terlebih dahulu mencari tingkat penggunaan beras/hari dengan menggunakan rumus sebagai berikut :

ROP :

$$
\begin{aligned}
\mathrm{u}= & \mathrm{Q} \\
& =\frac{12.000}{360 \text { Hari }} \\
& =33
\end{aligned}
$$

Maka, dapat dihitung titik pemesanan kembali (ROP)

$$
\begin{aligned}
\text { ROP } & =(\mathrm{u} \times \mathrm{L})+\mathrm{SS} \\
& =(33 \times 3 \text { hari })+267 \\
& =99+267 \\
& =366 \mathrm{Sak}
\end{aligned}
$$

Jadi, ROP adalah sebesar 366 Sak beras.

Berdasarkan perhitungan diatas maka, ROP atau titik pemesanan kembali akan dilakukan saat persediaan beras pada perusahaan berjumlah 366 sak, hal ini berarti bahwa beras yang di pesan tersebut akan diterima pada saat persediaan berjumlah nol yang tentu berdasarkan pada lead time. Untuk menghindari resiko kehabisan stok beras maka Toko Bali Yasa harus menetapkan suatu jumlah persediaan minimum (Safety Stock), guna mengantisipasi kekosongan persediaan beras dalam memenuhi kebutuhan konsumen.

\section{Pembahasan}

Berdasarkan hasil penelitian yang telah dilakukan, serta perhitungan-perhitungan dengan metodemetode yang sebelumnya telah di tentukan, maka dengan demikian dapat diketahui jumlah persediaan yang optimal agar tidak terjadi kelebihan ataupun kekurangan persediaan. Perhitungan tersebut dapat mengoptimalkan jumlah persediaan dengan menentukan berapa jumlah barang yang harus dipesan setiap kali melakukan pemesanan, jumlah biaya pemesanan yang harus dikeluarkan setiap kali melakukan pemesanan, jumlah biaya penyimpanan yang dibutuhkan serta jumlah total persediaan yang paling optimal yang harus disediakan toko Bali Yasa Luwuk Banggai.
Dari hasil penelitian tersebut, yang kemudian diolah kembali sehingga didapatkan rincian-rincian biaya serta jumlah pemesanan barang pada toko Bali Yasa Luwuk Banggai. Dari pengolahan data tersebut, diperoleh bahwa toko Bali Yasa Luwuk Banggai melakukan pemesanan sebanyak 60 kali pemesanan dalam kurun waktu selama satu tahun dengan jumlah pemesanan sebanyak 12.000 sak beras. Dari setiap kegiatan toko Bali Yasa Luwuk Banggai membutuhkan biaya-biaya seperti biaya pemesanan sebesar Rp. 120.000.000,-, dan biaya penyimpanan sebesar Rp. 27.400.000,-. Sehingga total biaya yang harus di keluarkan toko Bali Yasa Luwuk Banggai sebagai biaya-biaya persediaan adalah sebesar Rp. 147.400.000,-.

Untuk mengoptimalkan seluruh biayabiaya yang dikeluarkan dalam penelitian tersebut, dapat menggunakan metode Economic Order Quantity (EOQ). Berdasarkan metode tersebut, jumlah pesanan yang harus dilakukan adalah sebanyak 592 sak beras dengan frekuensi pemesanan sebanyak 20 kali selama satu tahun. Penghitungan jumlah biaya-biaya dengan metode ini akan mengeluarkan jumlah biaya pemesanan sebesar Rp. 40.540.540,- sedangkan untuk biaya penyimpanan adalah sebesar Rp. 40.552.000,-. Sehingga dengan menggunakan metode EOQ toko Bali Yasa Luwuk Banggai dapat meminimalisir pengeluaran biaya menjadi Rp. 81.092.540,-. Penerapan metode ini dapat menghemat pengeluaran biaya usaha sebesar Rp. 66.307.460,-.

Kuantitas persediaan pengaman menurut kebijakan toko Bali Yasa Luwuk Banggai tidak adanya persediaan pengaman. Sedangkan berdasarkan analisis metode EOQ kuantitas persediaan yang dicadangkan sebagai pengaman dari resiko kehabisan stok (Stock out) yaitu sebesar 267 sak beras.

Setiap perusahan tentunya harus memperhatikan jumlah persediaan yang terdapat dalam gudangnya, sehingga dapat meminimalisir terjadinya kekurangan ataupun kelebihan persediaan berasnya. Hal itu bertujuan agar tidak mengurangi tingkat kualitas beras ataupun nilai jual beras itu sendiri. Selain itu juga, hal ini bertujuan agar tidak menambah biaya yang harus dikeluarkan karena tingkat persediaan yang tidak sesuai. Sehingga, untuk mengatasi terjadinya hal tersebut perlu menggunakan sebuah metode agar dapat di ketahui pada jumlah berapakah pemesanan beras itu harus di lakukan. Berdasarkan data yang terdapat di atas bahwa 
pemesanan kembali atau Reorder Point (ROP) harus dilakukan pada saat persediaan beras berjumlah 366 sak.

Apabila melihat dari hasil perhitungan dari penelitian diatas, bahwa metode EOQ adalah metode yang sangat tepat untuk mengefisienkan jumlah biaya yang harus dikeluarkan dalam persediaan. Dengan metode EOQ kita dapat menentukan jumlah yang paling optimal untuk melakukan persediaan, yang bertujuan agar tidak terjadinya kehabisan stok dengan menggunakan metode Safety Stock, selain itu juga bertujuan agar tidak kelebihan persediaan dengan menetukan titik dimana harus melakukan pemesanan kembali pada saat persediaan berada pada jumlah tertentu dengan menggunakan metode Reorder Point (ROP).

Metode EOQ, Safety Stock, dan ROP akan menjadi metode yang sangat tepat apabila diterapkan untuk menentukan jumlah persediaan yang paling optimal pada Toko Bali Yasa Luwuk Banggai agar diperoleh biaya yang paling ekonomis yang dikeluarkan untuk setiap persediaan yang dilakukan.

\section{Kesimpulan dan Saran \\ Kesimpulan}

Dari hasil penelitian yang telah dilakukan, maka dapat disimpulkan beberapa poin penting yang diperoleh dari penelitian ini :

1) Bahwa berdasarkan data yang diperoleh dari perusahaan dan kemudian diolah kembali sehingga diketahui bahwa Toko Bali Yasa Luwuk Banggai melakukan pembelian beras dengan kuantitas sebanyak 60 kali pemesanan sepanjang tahun 2019. Sedangkan, apabila pembelian tersebut dilakukan berdasarkan metode EOQ, kuantitas pembelian beras tersebut hanya dilakukan sebanyak 20 kali dalam satu tahun.

2) Adapun biaya-biaya yang dikeluarkan dalam persediaan tersebut yaitu biaya pemesanan sebesar Rp.120.000.000,- sedangkan untuk biaya penyimpanannya sebesar Rp. 27.400.000,-. Sehingga total biaya yang harus dikeluarkan perusahaan sebagai biaya-biaya persediaan adalah sebesar Rp. 147.400.000,dalam satu tahun. Untuk mengoptimalkan biaya-biaya tersebut, dilakukan dengan menggunakan metode EOQ, sehingga diperoleh jumlah atau frekuensi pemesanan beras akan dilakukan sebanyak 20 kali pesan dengan jumlah pemesanan sebanyak 592 sak beras dengan biaya pemesanan sebesar Rp. 40.540.540,- sedangkan untuk biaya penyimpanan adalah sebesar Rp. 40.552.000,- Sehingga dengan menggunakan metode EOQ perusahaan dapat meminimalisir pengeluaran biaya menjadi Rp. 81.092.540,-. Penerapan metode ini dapat menghemat pengeluaran biaya perusahaan sebesar Rp. 66.307.460,-.

3) Untuk menjaga agar tidak terjadinya kehabisan stok beras, perusahaan dapat menerapkan metode EOQ dengan menggunakan turunan rumus dari Safety Stock yang diperoleh, dan perusahaan harus menyediakan persedian sebanyak 267 sak beras sebelum melakukan pemesana kembali atau Reorder Point (ROP) pada saat persediaan beras berjumlah 366 sak.

\section{Saran}

Setelah diadakan perhitungan dan menganalisis persediaan beras yang ada pada Toko Bali Yasa Luwuk Banggai, maka penulis mengajukan saran yang dapat dipertimbangkan oleh perusahaan untuk membuat kebijakan dalam melakukan persediaan beras. Saran-saran tersebut adalah sebagai berikut :

1) Perusahaan sebaiknya melakukan perhitungan fisik persediaan barang digudang secara berkala, setiap akhir bulan sehingga dapat mengetahui dengan segera jika terjadi kekeliruan atau kesalahan pencatatan dan adanya kekurangan stok maupun kelebihan ataupun penumpukan stok barang dagang.

2) Perusahaan perlu mengkaji kembali pengelolaan persediaan beras, dikarenakan setelah dilakukan penelitian, total biaya persediaan masih bisa diminimalkan. Dengan menggunakan metode EOQ dalam melakukan persediaan, perusahaan akan mendapatkan kuantitas pemesanan beras yang optimal dengan biaya yang minimum.

Perusahaan sebaiknya menerapkan perhitungan EOQ, ROP dan Safety Stock dalam pengelolaan dan pengendalian persediaan untuk menghindari adanya kekurangan stok (Stock Out) maupun kelebihan atau penumpukan stok beras dalam gudang. 


\section{Jumal ERonomi Trend Nol. 09 SNo. 01 Januari - Juni 2021 E-ISSN. 2722-6565}

\section{DAFTAR PUSTAKA}

Al Haryono, Jusup. 2005. Dasar-Dasar Akuntansi. Edisi 6. Yogyakarta

Antoillah, Anton. 2010. Dasar-Dasar Manajemen. CV Pustaka Setia. Bandung

Assauri, Sofyan. 1978. Manajemen Prouksi dan Operasi. LPSE UI. Jakarta

2004. Manajemen Produksi dan Operasi. CP- FEUI.Jakarta

Brantas,2009.Dasar-Dasar Manajemen. Lembaga penerbit Alfabeta.Bandung.

Fakultas Ekonomi. 2014.Pedoman Penyusunan dan Penulisan Skripsi. Luwuk:penerbit Istana digital Luwuk

Gitosudarmo, Indriyo. 2002 Manajemen Operasi Edisi 2 BPFE . Yogyakarta

Gulom, M. (2019). PENGARUH KOMPETENSI, DISIPLIN DAN LINGKUNGAN KERJA TERHADAP MUTU PELAYANAN PADA BANK PEMBANGUNAN DAERAH KABUPATEN TOJO UNA-UNA. Jurnal Ekonomi Trend, 7(2), 42-47. https://doi.org/10.31970/trend.v7i2.17 9

Haizer, Jay, dan Barry, Render. 2015. Operation Management (Manajemen Operasi). Edisi 11. Terjemahan Dwi Anoegrah Wati S dan Indra Almahdy. 2011. Salemba Empat. Jakarta

Herjanto, Eddy. 2010. Manajemen Operasi. Gramedia. Jakarta

Johanes, Agustinus Djohan. FIAS. 2016. Manajemen dan StrategiPembeliaan.Penerbit Media NusaCreative.Malang.

Kasmir. 2010.Pengantar Manajemen Keuangan. Kencana Prenada Media Group.Jakarta

Manullang, M. 2005. Dasar-Dasar Manajemen. Gadjah Mada University. Yogyakarta
Martono, Ricky.2015.Manajemen Logistik Terintegrasi.Penerbit PPM.Jakarta Pusat

Prawirosentono, Suyadi. 2005. Manajemen Operasi Edisi 4. Bumi Aksara. Jakarta.

Rangkuty, Freddy. 2004. Manajemen Persediaan. Edisi 2, Cetakan Keenam. Penerbit PT. Raja Grafindo Persada, Jakarta, hal 9.

2007. Manajemen Persediaan: Aplikasi Bidang Bisnis. Edisi 2Jakarta.PT. Raja Grafindo Persada.

Riyanto, Bambang. 2001. Dasar-Dasar Pembelanjaan Perusahaan. BBFE. Yogyakarta

Salim, F. U. (2020). PENGARUH ADVERSITY QUOTIENT DAN KOMPETENSI TERHADAP KINERJA KARYAWAN PT. ASKES (PERSERO) PALU. Jurnal Ekonomi Trend, 8(1), 26-34. https://doi.org/10.31970/trend.v8i1.18 3

Sangkota, M. (2020). PENGARUH SIKAP MENTAL, LINGKUNGAN KERJA DAN PENGHASILAN TERHADAP PRODUKTIVITAS KARYAWAN PT. UNGGUL WIDYA TEKNOLOGI LESTARI KABUPATEN MAMUJU UTARA. Jurnal Ekonomi Trend, 8(2), 32-37. https://doi.org/10.31970/trend.v8i2.19 6

Sugiyono. 2005. Metode Penelitian Bisnis. Alfabeta. Bandung.

2010. Metode Penelitian Pendekatan Kuantitatif, Kualitatif, dan $R \& D$. Alfabeta. Bandung.

Syahyunana,2004.ManajemenKeuanganI(Perenca naan, Analisis dan PengendalianKeuangan) USU Press. Medan 
Terry, George.2014.Prinsip-prinsip Manajemen.Jakarta. penerbit PT Bumi Aksara

Widodo, joko. 2001. Good Governance : Telaah dari Dimensi Akuntabilitas dan Kontrol Birokrasi Pada Era Desentralisasi dan Otonomi Daerah. Insan Cendekia. Surabaya. 